\title{
Which One Is the Most Dangerous: a Lion, the Lion, or Lions? A Study on the Acquisition of Generic Reference by Persian Learners
}

\author{
Marjansadat Momenzade \\ English Department, Faculty of Foreign Languages, University of Isfahan, Iran \\ Manijeh Youhanaee \\ English Department, Faculty of Foreign Languages, University of Isfahan, Iran \\ Zohreh Kassaian \\ English Department, Faculty of Foreign Languages, University of Isfahan, Iran
}

\begin{abstract}
An interesting area in second language acquisition research is the way the concept of generic reference is expressed in different languages. This study examines the role of the article system in the expression of generic noun phrases in English and focuses on the problems Persian learners face. Analysis of the performance of Persian learners at three levels of proficiency on a grammaticality judgment task and comparing it with that of the native control group shows that Persian learners of English at the advanced level of grammatical knowledge display a native-like knowledge of English generic constructions that include bare plurals or the indefinite NPs. They are, however, unable to show the same knowledge in definite generic constructions. It is discussed that this failure can be traced to be resulted from a strong $L 1$ transfer effect.
\end{abstract}

Index Terms-English article system, acquisition, definiteness, genericity, L1 transfer

\section{INTRODUCTION}

Being a teacher of English, one would often hear students complain about the difficulty they face when dealing with the English article system. This difficulty is also experienced and reported by educators as well as researchers in the field (McEldowney, 1977; Master, 1987; Krol-Markefka, 2008; Pashazade \& Marefat, 2010 to name just a few). As a result, abundant research exists on different aspects of the article system such as acquisition and pedagogy. However, looking through the bulk of research, one can easily figure out that most studies have so far concentrated on how articles, especially in English, are used to express in/definiteness or, more recently, the concept of specificity (Ionin, 2003; Hawkins et al., 2006; Avery \& Radisic, 2007; Hedberg et al., 2009; Atay, 2010).

It is, however, known that articles are also used to express the concept of 'genericity' in English. By definition, a generic noun phrase does not refer to a special or specific entity and so includes all the members of a class. That's why such noun phrases are specified as 'kind-referring' expressions. However, the literature on the article system in relation to the concept of genericity is not as rich as it is on the other aspects of article use. Moreover, most such studies have focused on the semantics of generic sentences or their features in discourse (Carlson, 1980; Carlson \& Pelletier, 2002; Juvan, 2005).

This study, in turn, was motivated by a desire to add to the existing literature on the generic reference in relation to the article system. In the following section, a review of studies on second language acquisition of generic reference in English is presented which is followed by a description of how generic reference is expressed in English and Persian. The fourth section provides information on the methodology of the study. The results of the study are presented in part five and then are discussed in part six. The last section concludes the study and presents some pedagogical implications.

\section{GENERICITY IN L2 ACQUISITION}

Snape et al. (2009) are truly right when they claim that 'little research has been conducted on the L2 acquisition of generic reference'. Most studies in the past three decades have focused on areas of article use other than the generic reference. Such studies have centered on article omission or misuse, access to semantic universals, or cognitive strategies. A few have also focused on pedagogical issues.

One piece of recent research to consult is Perez-Leroux et al. (2004). They investigated the acquisition of generic reference by L1 Spanish children learning English. They only considered bare plural generics in their study since in Spanish both bare plurals and definite plurals can have a generic sense but in English definite plurals cannot be interpreted as 'kind-referring'. They assumed that the definite article is semantically the same in both languages but in English the bare plural blocks the definite plural generic. They predicted that children in both languages would allow 
generic interpretations of the definite plural but to different degrees. In other words, the rate of acceptance of generic interpretations for the definite plural nouns would not be identical for both languages. Such interpretations would be fewer for English definite plurals. As for the results, their L1 Spanish subjects showed a 100\% preference for the generic reading of definite plurals in English, as they had predicted. The English children showed a reliable discrimination between definites and bare plurals. Nevertheless, they produced high rates of definite generic errors in their L1. The study concluded with highlighting the role of the first language in second language acquisition.

Another study on the generic use of articles is Ionin \& Montrul's (2009). Like the previous study, they examined L2 acquisition of generic reference with bare plurals. Their subjects were from an article-less language (Korean) learning English as a foreign language. For an article-less language like Korean, the choice between bare and definite plural generics does not arise. A bare plural typically has a generic reference. It can also have a specific reference when used anaphorically. They hypothesized that L1 Korean learners would, like L1 Spanish learners, overuse definite plurals for generic reference, a hypothesis which was supported by the study. A truth value judgment task and an acceptability judgment task were used to elicit data from the adult Korean participants. As expected, the learners were target-like in accepting definite plurals with a specific interpretation and bare plurals with a generic interpretation, but were for the most part unable to reject bare plurals with a specific interpretation. The researchers, then, presented patterns of transfer from Korean which had caused the wrong interpretation of definite plurals.

The last study to be mentioned here is Snape et al. (2009). They chose learners of English from a variety of language backgrounds (Spanish, Turkish, Japanese, and Chinese) to see the effect of first language on the second language acquisition of generic noun phrases in English. The variety of L1s in their study was significant because the four languages all differed to English. In Spanish, articles are obligatory so both definite and indefinite singular/plural nouns can be interpreted as generic. This is in contrast with English in which definite plural nouns cannot be interpreted as generic. Japanese and Chinese do not have an article system. There is also no count/mass distinction in such languages. In short, bare nominals are used; singular nouns can be interpreted as generic in appropriate context; and plural nouns cannot be interpreted as generic. Turkish has no article system either but there are three ways to express genericity in Turkish: plural nouns, unmarked phrases, and bir-phrases. A forced choice elicitation task was used as the instrument. The results were as the researchers had expected. Their Spanish subjects were much more successful than the others because Spanish is a [+article] language like English but as the writers had predicted, Spanish learners at lower levels of proficiency had problems in bare plural cases due to persistent L1 transfer. Again, L1 transfer helped Turkish learners do well in indefinite singular contexts but the definite singular context was problematic for them as Turkish does not have a definite article. This again pointed to a strong L1 transfer effect. Japanese learners overused 'the' in indefinite and plural contexts since bare plurals do not exist in their L1. And finally, Chinese learners produced omission and substitution errors in all singular contexts. Like Japanese, Chinese learners substituted 'the' in bare plural contexts. What this study comes to in the end is that L1 does have a strong influence on the L2 acquisition of English articles.

\section{GENERICITY IN ENGLISH AND PERSIAN}

Before presenting the study, it is necessary to provide a sketch of generic noun phrases in English and Persian. Genericity is a shared concept in both languages but its realization is somewhat different.

\section{A. Generic Noun Phrases in English}

There is a general consensus that the concept of genericity in English can be expressed in three ways:

a. Definite article + singular NP: The beaver builds dams.

b. Indefinite article + singular NP: A beaver builds dams.

c. Zero article + plural NP: Beavers build dams.

It must, of course, be added that for non-count nouns in a generic sense, zero article is used. For example:

d. Zero article + mass NP: Chocolate is the major ingredient for most kinds of cakes.

In their article, Smólska and Rusiecki (1980) discuss differing views on the three types of genericity in English. Whereas a few researchers believe that the above mentioned three forms are the same and, in fact, interchangeable (Robbins, 1970), there are some who believe the forms are not interchangeable and denote different meanings (Quirk et al., 1972; Langendoen, 1970). Also, in most books and research articles that are written on the concept of the generic noun phrase, the examples that are given all show generic NPs in subject position. Examples including generic nouns as object of the sentence are not usually provided. The reason might be that in object position, the three forms of generic nouns are not obviously interchangeable. An example is given below:

1. I don't like dogs.

It would obviously be odd to use the alternative forms of generic NPs for the noun in question (dogs). This seems to support those who believe that the forms are not interchangeable. This line of discussion is not, however, more elaborately presented here as it is not of interest to this study. The present study is based on the concept of generic noun phrases as "kind-referring expressions" that do not refer to a specific referent.

\section{B. Generic Noun Phrases in Persian}

The concept of genericity is stated in two ways: 
e. Bare singular NP: shotor behtærin væsileh bæraye sæfær dær biyaban æst. camel best-superlative means for travel in desert is.

"The camel is the best means for travelling in the desert."

f. Bare plural NP: golha be nur ehtiyaj darænd. flower-plural to light need have-3rd plural

"Flowers need light."

Two points are worth attention with regard to the generic NPs in Persian. First, bare plural NPs are not necessarily generic. A bare plural NP can also be interpreted as definite based on the context. An example would clarify the point:

2. bache-ha gol dust darænd.

child-plural flower like have-3rd plural

"Children like flowers."

The above sentence would be interpreted as generic. But it is quite common for the speaker to refer to his/her own children in which case the resulting NP would be definite and the equivalent English translation would be "The children like flowers". It is the context, then, which determines the appropriate interpretation of the NP.

Second, bare plural NPs cannot be used interchangeably with bare singular NPs in all contexts. As an example:

3. diruz bærash gol xaridæm.

yesterday for-her flower buy-1st singular

"I bought flowers for her yesterday."

The generic bare singular NP in this sentence (gol) cannot be substituted with its bare plural form:

4. *diruz bærash gol-ha xaridæm.

*yesterday for-her flower-plural buy-1st singular

*"I bought flowers for her yesterday."

Although the English equivalent would be correct, this not the way it is in Persian. In other words, there are restrictions on the use of bare singular/plural generic nouns in Persian.

Clearly, there are differences between the two languages. For one thing, the first type of generic NP in English that is listed above (definite singular nouns) is not found in Persian due to the fact that there is no equivalent to the English definite article. For another, an NP that is marked by the indefinite article (which is overtly realized in Persian) cannot be interpreted as generic under any circumstances. In other words, the second type of English generic construction that is listed above is impossible in Persian. The only point of similarity that can be observed between the two languages is the third type of generic construction. Bare plurals can be used in a generic sense in both Persian and English. So, in Persian, only bare singular nouns and bare plural nouns can be interpreted as generic.

\section{ThE PRESENT STUDY}

Considering the EFL context in which Persian learners study English and the differences in the expression of generic reference in English and Persian, the present study seeks answers to the following questions:

\section{A. Research Questions}

$\sqrt{ }$ Can Persian learners arrive at a native like knowledge of genericity in English as a foreign language?

$\sqrt{ }$ In which type of generic noun phrases in English do such learners have more problems?

\section{B. Method}

Participants. Forty three Iranian learners and teachers of English at Sheikhbahaee University took part in the present study. Initially, they took the Oxford Placement Test (2011) based on which their level of grammatical knowledge was determined and three groups of grammatical proficiency were identified. In the highly advanced group, learners and teachers who could score 55-60 on the OPT were placed. They had an age range of 25-40. This group included 11 people. The intermediate group consisted of those participants who could score 40-45 on the OPT. They were 14 in number and 19-27 years old. The elementary group included 18 participants who scored 25-30 on the placement test. They had the same age range as the intermediate group. The researchers preferred to include bigger gaps between groups than is considered in the original OPT manual because we wanted to make sure that the groups truly belonged to different levels of L2 knowledge. Fifteen native speakers were also included in the study as the control group. They were 9 males and 6 females and aged 8-34. They all were originally Americans having lived in their home county all their lives.

Instrument. The measurement in the present study was a grammaticality judgment test. Each item on the test included two sentences the first of which provided the necessary context for the interpretation of the second one. The noun phrase in question was placed in the second sentence. The participants were asked to determine if the second sentence was correct or not in the context of the first. They were also asked to correct the second sentence in case they thought it were wrong. An example item is given below:

2. Whenever I lose something, my dog finds it for me. Dogs are very intelligent. $\sqrt{ } *$ ? 
The test included 56 items 28 of which were of interest to this study. The rest of the items tested other uses of articles (definite, indefinite) and also other aspects of grammar (tense for example) and were included to distract learners' attention from the point being tested. The following table represents the GJ make-up:

TABLE I.

TYPES OF GENERIC SENTENCES ON THE GJ TEST

\begin{tabular}{|l|l|l|}
\hline Test category & $\begin{array}{l}\text { Target } \\
\text { article }\end{array}$ & Example \\
\hline $\begin{array}{l}\text { Bare plural, } \\
\text { Correct }\end{array}$ & $\varnothing$ & Whenever I lose something, my dog finds it for me. Dogs are very intelligent. \\
\hline $\begin{array}{l}\text { Definite plural, } \\
\text { Incorrect }\end{array}$ & $\varnothing$ & Allan has a farm. He grows the cabbages there. \\
\hline $\begin{array}{l}\text { Definite singular, } \\
\text { Correct }\end{array}$ & the & Many people like to have pets. But just a few of them keep the snake as a pet. \\
\hline $\begin{array}{l}\text { Indefinite singular, } \\
\text { Correct }\end{array}$ & a & $\begin{array}{l}\text { The sense of smell is very strong in animals. However, a dog has a stronger sense of hearing } \\
\text { than smelling. }\end{array}$ \\
\hline $\begin{array}{l}\text { Bare singular, } \\
\text { Incorrect }\end{array}$ & the/a & $\begin{array}{l}\text { People have changed the way they spend their free time. Today, you can find television in every } \\
\text { house. }\end{array}$ \\
\hline $\begin{array}{l}\text { Bare mass, } \\
\text { Correct }\end{array}$ & $\varnothing$ & What would you like best for dessert? Oh, I prefer ice cream to the rest. \\
\hline $\begin{array}{l}\text { Definite mass, } \\
\text { Incorrect }\end{array}$ & $\varnothing$ & Do you know what the most common food in Asia is? I think it is the bread. \\
\hline
\end{tabular}

Data collection and analysis.Data collection took two weeks. The first test to be run was the placement test (OPT) and the participants took the GJ test in the following week. On the GJ test, each correct answer was worth one score and each incorrect one was given a zero score. Also, for each incorrect item on the test, only if the participant had circled '*' and supplied the right answer, s/he was scored 'one'. To put it differently, just circling '*' was not enough to indicate that the sentence was wrong and that the participant necessarily knew which part of the sentence made it ungrammatical. For the correct answers as well, the participants had to mark ' $\sqrt{ }$ ' to merit a 'one' score. They weren't granted any scores if they had left the sentence intact. And the intact sentences were dismissed when scoring.

The coded data was submitted to the Statistical Packages in Social Sciences (SPSS, 16.0) software for the purpose of analysis. For each category on the test, the mean percentage for each individual participant and later for each proficiency group was calculated. Since there were four groups of participants and one independent variable, one-way between groups ANOVA was performed as the proper statistical procedure to see if inter-group differences existed with regard to the feature in question (genericity).

\section{RESULTS}

To arrive at an answer to the first research question, the participants' performance on the generic items of the test was checked and compared with the native control group. Among the three proficiency groups, the participants were not the same. Furthermore, their performance was quite different from that of the native speakers. This can be observed in Fig. 1.

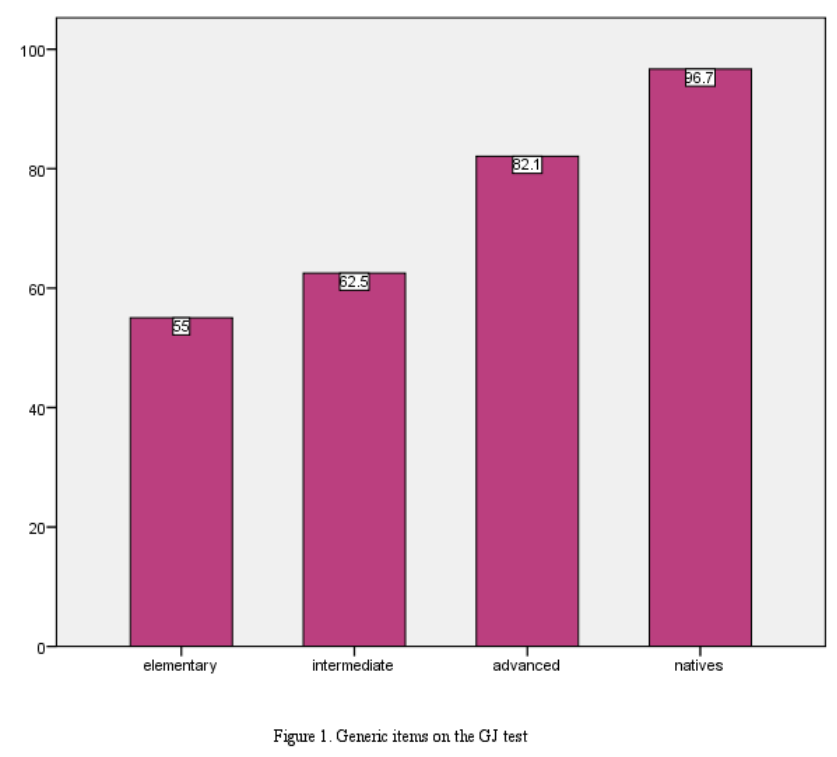


One way analysis of variance showed that the difference among the groups was significant at 0.05 level. (Table II)

TABLE II.

ANOVA RESULTS FOR THE GENERIC ITEMS ON THE GJ TEST

\begin{tabular}{|l|l|l|l|l|l|}
\hline & Sum of Squares & df & Mean Square & F & Sig. \\
\hline Between Groups & 15494.283 & 3 & 5164.761 & 55.111 & .000 \\
\hline Within Groups & 4873.194 & 52 & 93.715 & & \\
\hline Total & 20367.477 & 55 & & & \\
\hline
\end{tabular}

Further, the Scheffe post-hoc test (Appendix A) revealed that the elementary and the intermediate groups were not significantly different but that the difference in performance was observed to be significant between the native control group and the other proficiency groups. In other words, the highly advanced group did in fact outperform the lower proficiency groups but still could not conform to the native speaker norm.

For the second research question, the generic items on the test were sorted out and classified into the original three groups. Fig. 2 depicts how the participants performed on each item type.

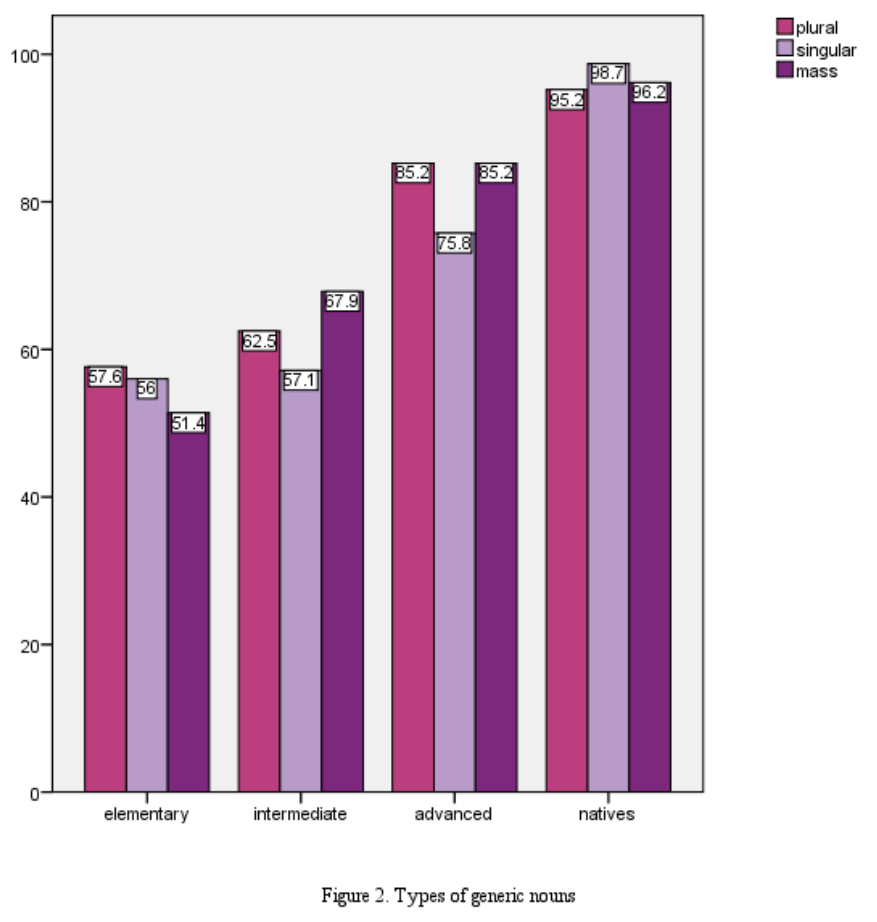

Again, one-way ANOVA pointed to significant differences among groups in all three types of generic nouns. (Table III)

TABLE III.

ANOVA RESULTS FOR PERFORMANCE ON GENERIC TYPES

\begin{tabular}{|l|l|l|l|l|l|l|}
\hline \multirow{3}{*}{ plural } & & Sum of Squares & df & Mean Square & F & Sig. \\
\cline { 2 - 7 } & Between Groups & 13837.892 & 3 & 4612.631 & 24.370 & .000 \\
\cline { 2 - 7 } & Within Groups & 9842.354 & 52 & 189.276 & & \\
\cline { 2 - 7 } & Total & 23680.246 & 55 & & & \\
\hline \multirow{4}{*}{ mingular } & Between Groups & 16918.526 & 3 & 5639.509 & 27.434 & .000 \\
\cline { 2 - 7 } & Within Groups & 10689.361 & 52 & 205.565 & & \\
\cline { 2 - 7 } & Total & 27607.887 & 55 & & & \\
\cline { 2 - 7 } & Between Groups & 17379.272 & 3 & 5793.091 & & .000 \\
\cline { 2 - 7 } & Within Groups & 12751.866 & 52 & 245.228 & & \\
\cline { 2 - 7 } & Total & 30131.138 & 55 & & & \\
\hline
\end{tabular}

Using a post-hoc Scheffe test (Appendix B), it was observed that the Persian learners did display a native-like knowledge on bare plural generics and mass generics at the highly advanced level. At the lower proficiency levels, the situation was not so. The elementary and the intermediate learners could not do as well as the advanced group or the natives. The other category, that of singular generics, was problematic even for the advanced group and a significant difference existed between them and the native control group.

It seemed, therefore, that the singular generic noun phrases were the source of problem for Persian learners since they could finally display a good-enough knowledge of the other two types (bare plural and mass generic NPs). Looking more closely at the two types of singular generics (Table IV) revealed that Persian learners were not different from the 
control group in their performance on recognizing the correct indefinite singular nouns. But the one-way analysis of variance detected a significant difference among the groups in their recognition of the correct definite singular nouns on the test.

TABLE IV.

ANOVA RESULTS FOR PERFORMANCE ON SINGULAR GENERIC NOUNS

\begin{tabular}{|l|l|l|l|l|l|l|}
\hline \multirow{3}{*}{ definite } & & Sum of Squares & df & Mean Square & F & Sig. \\
\cline { 2 - 7 } & Between Groups & 9469.359 & 3 & 3156.453 & 5.540 & .002 \\
\cline { 2 - 8 } & Within Groups & 29626.623 & 52 & 569.743 & & \\
\cline { 2 - 8 } & Total & 39095.982 & 55 & & & \\
\hline \multirow{5}{*}{ indefinite } & Between Groups & 1741.349 & 3 & 580.450 & 1.657 & .188 \\
\cline { 2 - 8 } & Within Groups & 18214.008 & 52 & 350.269 & & \\
\cline { 2 - 7 } & Total & 19955.357 & 55 & & & \\
\hline
\end{tabular}

Results from a Scheffe post-hoc test showed that the difference was significant between the control group on the one hand, and the intermediate and advanced groups on the other (Appendix C). It was revealed then, that the major obstacle the Persian learners in this study were facing was the definite article. So, the participants did, in fact, accept the indefinite singular nouns as kind-referring in the contexts provided in the test but did not do so for the definite singular nouns. Fig. 3 helps with the visualization.

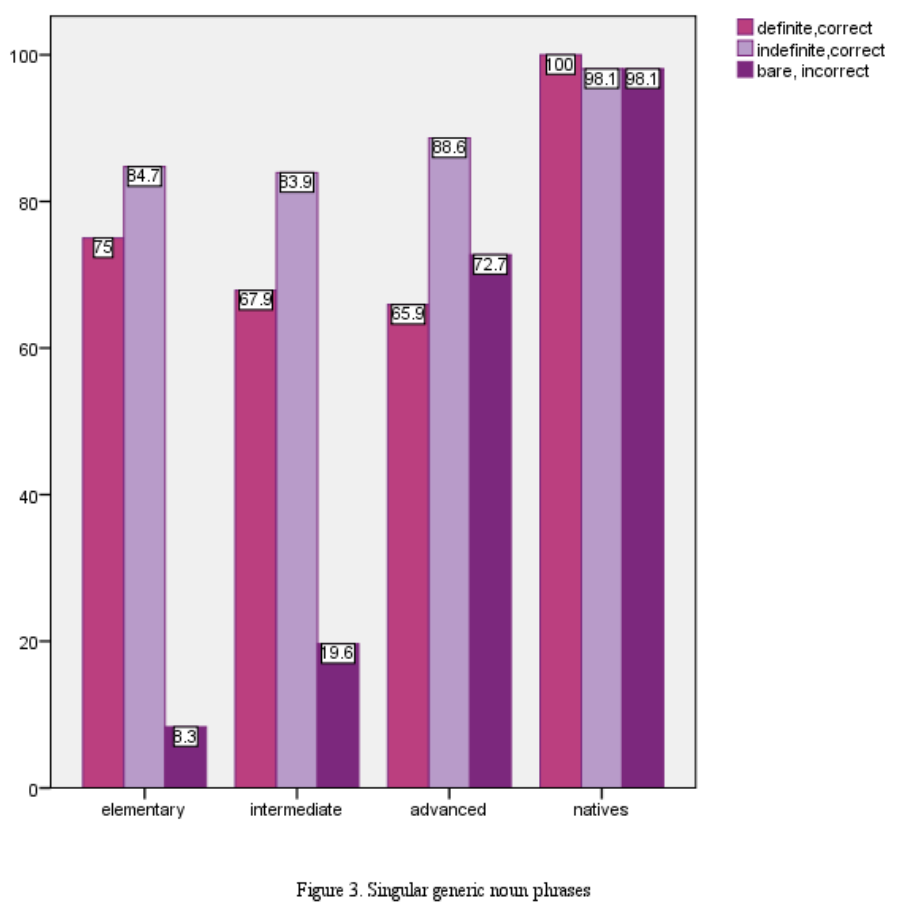

One can see, also, that learners at all the three levels did not display a good ability to correct the incorrect items. At the elementary level, they were literally unable to make any corrections as $92 \%$ of such incorrect sentences were accepted as correct. Although learners improved at higher levels, there was still a long distance between the advanced learners and the natives. Analyzing the corrections such learners had made showed that they preferred zero article and indefinite article to definite article in their corrections. The following table shows how the advanced group supplied the needed article in the incorrect sentences. We focused on the advanced participants since few corrections had been made by the other two proficiency groups. There were four incorrect sentences on the test.

TABLE V.

ARTICLE SUPPLEMENT BY THE ADVANCED GROUP

\begin{tabular}{|l|l|l|l|l|}
\hline & \multicolumn{3}{|c|}{ supplied article } & \\
\hline No & correct answers (\%) & $\varnothing+$ plural NP & The + NP & A + NP \\
\hline 1 & 91 & $80 \%$ & $20 \%$ & 0 \\
\hline 2 & 64 & 0 & 0 & $100 \%$ \\
\hline 3 & 91 & $60 \%$ & $10 \%$ & $30 \%$ \\
\hline 4 & 45 & 0 & 0 & $100 \%$ \\
\hline
\end{tabular}

It is interesting to notice that the advanced learners preferred to change the whole sentence into plural form (so they had to pluralize the noun and consequently change the original singular verb) in order to use the bare plural as expressing the intended generic meaning. 


\section{DISCUSSION}

The participants in this study showed some progress in the use of articles with generic nouns as their proficiency increased (Fig. 1); but their performance was not still as good as the native speakers in the control group. Even at the highly advanced level of grammatical knowledge, Persian learners could not be said to have arrived at a native-like knowledge of English generic nouns and, so, the answer to the first research question was negative.

It was explained above that generic NPs are not marked with any articles in Persian. Bare singular or plural nouns are used in the generic sense. It can be said, therefore, that although the concept of 'genericity' in English is tied up with that of 'number' and 'definiteness', in Persian it is just tied up with 'number'. So, if one can claim that all three features in question (genericity, definiteness, number) exist in both languages, one would expect learner problems to be of a different nature other than acquisition.

Learners in this study had a native-like performance on generic bare plural and generic mass NPs but only at the advanced level. It would have been quite reasonable to expect such good performance at the elementary and intermediate levels as well since the same constructions are used in Persian. The question remains as to why learners, having acquired those features in their L1, did not show such mastery in lower levels of proficiency (Fig. 2). Analysis of their test results showed that the elementary and intermediate learners were almost perfectly able to recognize the correct sentences containing a generic bare plural noun phrase $(94 \%)$ or a generic mass noun phrase $(80 \%)$. That's because they are expressed exactly alike in the two languages. Such noun phrases are preceded by a zero article in English as well as Persian. Their low performance compared with the advanced and the control groups, then, was due to their inability to recognize and correct the wrong sentences on the test. Such sentences included NPs like [the + plural noun] or [the + mass noun]. This showed that learners in our study did not know, at that level of proficiency, that a definite article could not be used with a plural or mass noun when they were to be interpreted as generic. In other words, such learners had not yet learned the functions and interpretations of the definite article in English. If they had, they would have known that a construction like [the+ mass noun] would be interpreted as 'definite' and not 'generic'. So they continued to use 'the' for all types of nouns without knowing the difference it could make.

Looking at Fig. 3 above, some points are worth attention. First, as learners grammatical knowledge developed, they showed a tendency to reject definite singular nouns in their generic interpretation more often though the rate of acceptance was perfect $(100 \%)$ for the control group. Analysis of the advanced learners' answers on the test showed that when they considered such noun phrases as wrong, they had three options: they preferred a zero article to be used with the singular noun (30\%) which is exactly how such nouns would be used in Persian, hence a direct L1 transfer effect. In other times, they supplied the indefinite article instead of the definite one (27\%) or used a bare plural (7\%). This use of the indefinite article for generic nouns shows that even advanced learners in our study did not know that the definite article can also convey genericity for singular nouns.

Second, learners highly accepted the indefinite article accompanying singular generic nouns from low levels of knowledge. This can be interpreted as showing that when genericity is concerned, using an indefinite article with a singular noun is far more acceptable for Persian learners than using a definite article to show the same concept. The second one takes them a much longer time to learn.

Third, as their level of grammatical knowledge developed, learners showed a better knowledge of generic NPs in English as they were better able to correct the incorrect sentences on the test. Those sentences included a bare singular noun. The very low levels of corrections at the elementary level (9\%) and the intermediate level (20\%) point to a strong transfer effect for such learners. This effect was still powerful enough to mislead the advanced students since they accepted a good proportion of such sentences as correct (27\%) which made them different from the native speakers on the test. When the advanced learners made corrections, they preferred the indefinite article (45\%) to the definite article $(7 \%)$ or the bare plural form $(20 \%)$. This, again, points to our conclusion earlier that the generic use of 'a' is far sooner learned than that of 'the'.

\section{CONCLUSION}

The participants in this study did not show the capability to match up to the native control participants in their recognition and production of generic noun phrases in English. Analyzing their performance on different types of the generic noun phrase, it was revealed that they had a good knowledge of bare plural NPs and indefinite NPs in the generic sense that enabled them to ultimately conform to the norm of the native speakers once they were at the very advanced level of grammatical proficiency. The same highly advanced learners had; however, a very impoverished knowledge of generic singular NPs. Further analysis of their performance revealed that these learners had serious problems in recognition and production of definite singular NPs in generic sentences. L1 transfer effects were considered responsible for such deficiency in learners' knowledge.

It is a well known fact among Persian researchers and teachers that Persian learners have many more problems with the definite article 'the' in English than with the indefinite article. While previous research on the English articles in Iran has almost entirely focused on the concept of 'definiteness' expressed by 'the', this study adds to the literature useful information about the fact that 'the' is also problematic for learning the concept of genericity as well. 
The results of this research might hopefully shed some light on such corners of grammatical knowledge that seem to have been neglected by practitioners for so long. Knowing that very few proficient learners and even teachers are aware of uses of 'the' other than 'for expressing definite objects' is a warning to those who would wish to improve the quality of teaching English in language classes. We believe that once the problematic part is pinpointed, many suggestions can easily be made and tested in practice (consciousness raising tasks, implicit techniques, et) to heighten our knowledge in this important aspect of article use in English.

\section{APPENDIX A. SCHEFFE Results For PERFormance On [+GENERIC] Nouns}

\begin{tabular}{|c|c|c|c|c|c|c|}
\hline \multirow{2}{*}{$\begin{array}{l}\text { (I) proficiency } \\
\text { groups }\end{array}$} & \multirow{2}{*}{$\begin{array}{l}\text { (J) proficiency } \\
\text { groups }\end{array}$} & \multirow{2}{*}{$\begin{array}{l}\text { Mean Difference } \\
(\mathrm{I}-\mathrm{J})\end{array}$} & \multirow[t]{2}{*}{ Std. Error } & \multirow[t]{2}{*}{ Sig. } & \multicolumn{2}{|c|}{$95 \%$ Confidence Interval } \\
\hline & & & & & Lower Bound & Upper Bound \\
\hline \multirow[t]{3}{*}{ elementary } & intermediate & -7.485 & 3.450 & .208 & -17.45 & 2.48 \\
\hline & advanced & $-27.055^{*}$ & 3.705 & .000 & -37.76 & -16.35 \\
\hline & natives & $-41.673^{*}$ & 3.524 & .000 & -51.85 & -31.49 \\
\hline \multirow{3}{*}{ intermediate } & elementary & 7.485 & 3.450 & .208 & -2.48 & 17.45 \\
\hline & advanced & $-19.571^{*}$ & 3.900 & .000 & -30.84 & -8.30 \\
\hline & natives & $-34.188^{*}$ & 3.729 & .000 & -44.96 & -23.42 \\
\hline \multirow[t]{3}{*}{ advanced } & elementary & $27.055^{*}$ & 3.705 & .000 & 16.35 & 37.76 \\
\hline & intermediate & $19.571^{*}$ & 3.900 & .000 & 8.30 & 30.84 \\
\hline & natives & $-14.617^{*}$ & 3.966 & .007 & -26.08 & -3.16 \\
\hline \multirow[t]{3}{*}{ natives } & elementary & $41.673^{*}$ & 3.524 & .000 & 31.49 & 51.85 \\
\hline & intermediate & $34.188^{*}$ & 3.729 & .000 & 23.42 & 44.96 \\
\hline & advanced & $14.617^{*}$ & 3.966 & .007 & 3.16 & 26.08 \\
\hline
\end{tabular}

APPENDiX B. SchefFe Results FOR PERFORMANCE ON THREE TyPES OF [+GENERIC] Nouns

\begin{tabular}{|c|c|c|c|c|c|c|c|}
\hline \multirow{2}{*}{$\begin{array}{l}\text { Dependen } \\
\text { t Variable }\end{array}$} & \multirow{2}{*}{$\begin{array}{l}\text { (I) proficiency } \\
\text { groups }\end{array}$} & \multirow{2}{*}{$\begin{array}{l}(\mathrm{J}) \text { proficiency } \\
\text { groups }\end{array}$} & \multirow{2}{*}{$\begin{array}{l}\text { Mean Difference } \\
(\mathrm{I}-\mathrm{J})\end{array}$} & \multirow{2}{*}{ Std. Error } & \multirow{2}{*}{ Sig. } & \multicolumn{2}{|c|}{ 95\% Confidence Interval } \\
\hline & & & & & & Lower Bound & Upper Bound \\
\hline \multirow[t]{12}{*}{ plural } & \multirow[t]{3}{*}{ elementary } & intermediate & -4.861 & 4.903 & .805 & -19.03 & 9.30 \\
\hline & & advanced & $-27.588^{*}$ & 5.265 & .000 & -42.80 & -12.38 \\
\hline & & natives & $-37.553^{*}$ & 5.007 & .000 & -52.02 & -23.09 \\
\hline & \multirow[t]{3}{*}{ intermediate } & elementary & 4.861 & 4.903 & .805 & -9.30 & 19.03 \\
\hline & & advanced & $-22.727^{*}$ & 5.543 & .002 & -38.74 & -6.71 \\
\hline & & natives & $-32.692^{*}$ & 5.299 & .000 & -48.00 & -17.38 \\
\hline & \multirow[t]{3}{*}{ advanced } & elementary & $27.588^{*}$ & 5.265 & .000 & 12.38 & 42.80 \\
\hline & & intermediate & $22.727^{*}$ & 5.543 & .002 & 6.71 & 38.74 \\
\hline & & natives & -9.965 & 5.636 & .382 & -26.25 & 6.32 \\
\hline & \multirow[t]{3}{*}{ natives } & elementary & $37.553^{*}$ & 5.007 & .000 & 23.09 & 52.02 \\
\hline & & intermediate & $32.692^{*}$ & 5.299 & .000 & 17.38 & 48.00 \\
\hline & & advanced & 9.965 & 5.636 & .382 & -6.32 & 26.25 \\
\hline \multirow[t]{12}{*}{ singular } & \multirow[t]{3}{*}{ elementary } & intermediate & -1.124 & 5.109 & .997 & -15.89 & 13.64 \\
\hline & & advanced & $-19.739^{*}$ & 5.487 & .009 & -35.59 & -3.89 \\
\hline & & natives & $-42.699^{*}$ & 5.219 & .000 & -57.78 & -27.62 \\
\hline & \multirow[t]{3}{*}{ intermediate } & elementary & 1.124 & 5.109 & .997 & -13.64 & 15.89 \\
\hline & & advanced & $-18.615^{*}$ & 5.777 & .023 & -35.31 & -1.92 \\
\hline & & natives & $-41.575^{*}$ & 5.522 & .000 & -57.53 & -25.62 \\
\hline & \multirow[t]{3}{*}{ advanced } & elementary & $19.739^{*}$ & 5.487 & .009 & 3.89 & 35.59 \\
\hline & & intermediate & $18.615^{*}$ & 5.777 & .023 & 1.92 & 35.31 \\
\hline & & natives & $-22.960^{*}$ & 5.874 & .004 & -39.93 & -5.99 \\
\hline & \multirow[t]{3}{*}{ natives } & elementary & $42.699^{*}$ & 5.219 & .000 & 27.62 & 57.78 \\
\hline & & intermediate & $41.575^{*}$ & 5.522 & .000 & 25.62 & 57.53 \\
\hline & & advanced & $22.960^{*}$ & 5.874 & .004 & 5.99 & 39.93 \\
\hline \multirow[t]{12}{*}{ mass } & \multirow[t]{3}{*}{ elementary } & intermediate & $-16.468^{*}$ & 5.580 & .043 & -32.59 & -.35 \\
\hline & & advanced & $-33.838^{*}$ & 5.993 & .000 & -51.15 & -16.52 \\
\hline & & natives & $-44.765^{*}$ & 5.700 & .000 & -61.23 & -28.30 \\
\hline & \multirow[t]{3}{*}{ intermediate } & elementary & $16.468^{*}$ & 5.580 & .043 & .35 & 32.59 \\
\hline & & advanced & -17.370 & 6.309 & .068 & -35.60 & .86 \\
\hline & & natives & $-28.297^{*}$ & 6.032 & .000 & -45.72 & -10.87 \\
\hline & \multirow[t]{3}{*}{ advanced } & elementary & $33.838^{*}$ & 5.993 & .000 & 16.52 & 51.15 \\
\hline & & intermediate & 17.370 & 6.309 & .068 & -.86 & 35.60 \\
\hline & & natives & -10.927 & 6.415 & .415 & -29.46 & 7.61 \\
\hline & \multirow[t]{3}{*}{ natives } & elementary & $44.765^{*}$ & 5.700 & .000 & 28.30 & 61.23 \\
\hline & & intermediate & $28.297^{*}$ & 6.032 & .000 & 10.87 & 45.72 \\
\hline & & advanced & 10.927 & 6.415 & .415 & -7.61 & 29.46 \\
\hline
\end{tabular}


Appendix C. Scheffe Results for Performance on Singular Generic Nouns

\begin{tabular}{|c|c|c|c|c|c|c|c|}
\hline \multirow{2}{*}{$\begin{array}{l}\text { Dependen } \\
\text { t Variable }\end{array}$} & \multirow{2}{*}{$\begin{array}{l}\text { (I) proficiency } \\
\text { groups }\end{array}$} & \multirow{2}{*}{$\begin{array}{l}(\mathrm{J}) \text { proficiency } \\
\text { groups }\end{array}$} & \multirow{2}{*}{$\begin{array}{l}\text { Mean Difference } \\
(\mathrm{I}-\mathrm{J})\end{array}$} & \multirow[t]{2}{*}{ Std. Error } & \multirow[t]{2}{*}{ Sig. } & \multicolumn{2}{|c|}{ 95\% Confidence Interval } \\
\hline & & & & & & Lower Bound & Upper Bound \\
\hline \multirow[t]{12}{*}{ definite } & \multirow[t]{3}{*}{ elementary } & intermediate & 7.143 & 8.506 & .872 & -17.43 & 31.72 \\
\hline & & advanced & 9.091 & 9.135 & .804 & -17.30 & 35.48 \\
\hline & & natives & -25.000 & 8.688 & .051 & -50.10 & .10 \\
\hline & \multirow[t]{3}{*}{ intermediate } & elementary & -7.143 & 8.506 & .872 & -31.72 & 17.43 \\
\hline & & advanced & 1.948 & 9.617 & .998 & -25.84 & 29.73 \\
\hline & & natives & $-32.143^{*}$ & 9.194 & .011 & -58.71 & -5.58 \\
\hline & \multirow[t]{3}{*}{ advanced } & elementary & -9.091 & 9.135 & .804 & -35.48 & 17.30 \\
\hline & & intermediate & -1.948 & 9.617 & .998 & -29.73 & 25.84 \\
\hline & & natives & $-34.091^{*}$ & 9.779 & .012 & -62.34 & -5.84 \\
\hline & \multirow[t]{3}{*}{ natives } & elementary & 25.000 & 8.688 & .051 & -.10 & 50.10 \\
\hline & & intermediate & $32.143^{*}$ & 9.194 & .011 & 5.58 & 58.71 \\
\hline & & advanced & $34.091^{*}$ & 9.779 & .012 & 5.84 & 62.34 \\
\hline \multirow[t]{12}{*}{ indefinite } & \multirow[t]{3}{*}{ elementary } & intermediate & .794 & 6.669 & 1.000 & -18.48 & 20.06 \\
\hline & & advanced & -3.914 & 7.163 & .960 & -24.61 & 16.78 \\
\hline & & natives & -13.355 & 6.812 & .291 & -33.04 & 6.33 \\
\hline & \multirow[t]{3}{*}{ intermediate } & elementary & -.794 & 6.669 & 1.000 & -20.06 & 18.48 \\
\hline & & advanced & -4.708 & 7.541 & .942 & -26.49 & 17.08 \\
\hline & & natives & -14.148 & 7.209 & .290 & -34.98 & 6.68 \\
\hline & \multirow[t]{3}{*}{ advanced } & elementary & 3.914 & 7.163 & .960 & -16.78 & 24.61 \\
\hline & & intermediate & 4.708 & 7.541 & .942 & -17.08 & 26.49 \\
\hline & & natives & -9.441 & 7.667 & .680 & -31.59 & 12.71 \\
\hline & \multirow[t]{3}{*}{ natives } & elementary & 13.355 & 6.812 & .291 & -6.33 & 33.04 \\
\hline & & intermediate & 14.148 & 7.209 & .290 & -6.68 & 34.98 \\
\hline & & advanced & 9.441 & 7.667 & .680 & -12.71 & 31.59 \\
\hline
\end{tabular}

\section{REFERENCES}

[1] Atay, Z. (2010). Second language acquisition of the English article system by Turkish learners: The role of semantic notions. MA thesis, Middle East Technical University.

[2] Avery, P. \& M. Radišić. (2007). Accounting for variability in the acquisition of English articles. Proceedings of the 2nd Conference on Generative Approaches to Language Acquisition North America (GALANA), Alyona Belikova et al. (eds.), 1-11. Somerville, MA: Cascadilla Proceedings Project.

[3] Carlson, G. N. (1980). Reference to kinds in English. Garland Publishing Inc: New York \& London.

[4] Carlson, G. N. \& F. J. Pelletier. (2002). The average American has 2.3 children. Journal of semantics 19, 1-32.

[5] Hawkins, R. et al. (2006). Accounting for English article interpretation by L2 speakers. In S. Foster-Cohen, M. Medved Krajnovic \& J. Miihaljevic Djigunovic (eds.), EUROSLA Yearbook 2006,7-25. Amsterdam: John Benjamins.

[6] Hedberg. N., Görgül. E., \& Mamen. M. (2009). On definiteness and specificity in Turkish and Persian. Proceedings of the 2009 annual conference of the Canadian Linguistic Association.

[7] Ionin, T. (2003). Article semantics in second language acquisition. PhD dissertation, MIT.

[8] Ionin, T. \& S. Montrul. (2009). Article use and generic reference: Parallels between L1 and L2 acquisition. In M. Garcia-Mayo \& R. Hawkins (eds.), Second language acquisition of articles: Empirical findings and theoretical implications. Amsterdam: John Benjamins.

[9] Juvan, M. (2005). Generic identity and intertextuality. CLC Web: Comparative literature and culture 7.1, 1-11.

[10] Król-Markefka, A. (2008). Some theoretical considerations on the use of contrastive data in teaching English articles to Polish learners. Studia Linguistica125, 103-112.

[11] Langendoen, D. T. (1970). Essentials of English grammar. New York: Holt, Rinehart and Winston.

[12] Master, P. (1987). A cross-linguistic interlanguage analysis of the acquisition of the English article system. Ph.D. dissertation, UCLA.

[13] McEldowney, P. (1977). A teaching grammar of the English article system. International Review of Applied Linguistics 15.1, 95-112.

[14] Pashazadeh, A. \& H. Marefat. (2010). The long term effect of selective written grammar feedback on EFL learners' acquisition of articles. Pazhuhesh-e Zabanha-ye Khareji 56, 49-67.

[15] Pérez-Leroux, A., Munn, A., Schmitt, C. \& DeIrish, M. (2004). Learning definite determiners: Genericity and definiteness in English and Spanish. In A. Brugos, L. Micciulla \& C. Smith (eds)., BUCLD 28 Proceedings Supplement.

[16] Quirk, R. S., Greenbaum, G., \& Svartvik, J. (1972). A grammar of contemporary English. London: Longman.

[17] Robbins, B. F. (1970). The definite article in English transformations. The Hague: Mouton.

[18] Smólska, J., \& J. Rusiecki. (1980). The generic noun phrase in English and Polish. Papers and studies in contrastive linguistics $11,39-57$.

[19] Snape, N., Garcia Mayo, M. P., \& Gürel, A. (2006). Spanish, Turkish, Japanese and Chinese L2 learners' acquisition of generic reference. Proceedings of the 10th generative approaches to second language acquisition conference (GASLA). Somerville, MA: Cascadilla Proceedings Project. 
Marjansadat Momenzade is currently a PhD candidate at the University of Isfahan where she received her MA in Teaching English as a Foreign Language as well. She is also a member of faculty in the English department at the University of Sheikhbahaee. She has the experience of teaching the courses on different language skills, teaching, and translation to BA students at both Isfahan University and Sheikhbahaee University. Her fields of interest are second language acquisition, applied linguistics, language teaching, and translation.

Manijeh Youhanaee holds a PhD in language and linguistics from the University of Essex. She has co-authored with Badrizadeh "A Descriptive Dictionary of Theories of Generative Grammar". She has published a number of articles on the teaching/ acquisition of different English syntactic properties by native speakers of Persian. She teaches MA and PhD courses in linguistics, generative grammar, TEFL and SLA. Her areas of interest include syntactic theory, acquisition of L2 \& L3 syntax and issues in teaching and learning English as a second/foreign language.

Zohreh Kassaian was born in Isfahan, Iran. She received her BA degree in English Language and Literature from The University of Isfahan, Isfahan, Iran in 1973; her MA in Teaching English as a Second Language from the University of Shiraz, Shiraz, Iran in 1987; and her PhD in Teaching English as a Second Language from Islamic Azad University, Tehran, Iran in1996. She is an assistant professor in the English Department of the Faculty of Foreign languages at the University of Isfahan. She has participated in more than 20 national and international conferences and has more than 20 articles and several books published. Her subjects of interest are psycholinguistics, neurolinguistics, applied linguistics, phonetics, and translation. Dr. Kassaian has been a member of several professional societies including International Systemic Functional Linguistics, Iran Society of Teaching English Language and Literature, and The International Society of Scientific Collaboration for Iran Recognition. 